\title{
Dietary characterization of Savi's Warbler Locustella luscinioides and Great Reed Warbler Acrocephalus arundinaceus in eastern Spain
}

\author{
Sara Ferreiro-Carballal ${ }^{1, *}$, Eduardo J. Belda ${ }^{2}$, Francesco Ceresa ${ }^{1}$ \& Juan S. Monrós ${ }^{1}$
}

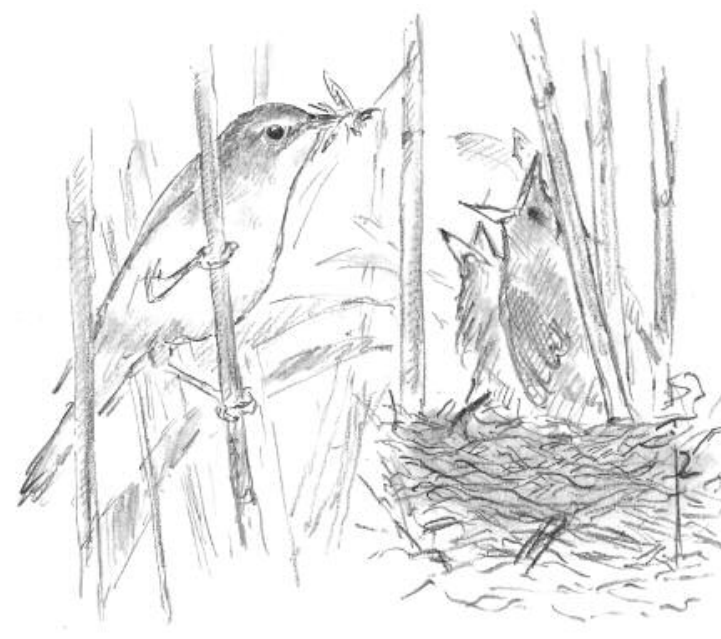

Ferreiro-Carballal S., Belda E.J., Ceresa F. \& Monrós J.S. 2017. Dietary characterization of Savi's Warbler Locustella luscinioides and Great Reed Warbler Acrocephalus arundinaceus in eastern Spain. Ardea 105: 79-83. doi:10.5253/arde.v105i1.a4

\begin{abstract}
This research deals with two insectivorous reedbed-nesting songbirds: the Savi's Warbler Locustella luscinioides and the Great Reed Warbler Acrocephalus arundinaceus, breeding at the Marjal de Pego-Oliva (Valencia-Alicante, Spain). We studied the diet and prey selection of the two species and assessed the dietary differences between them. Diet composition was assessed by examining samples of regurgitated food obtained using apomorphine as an emetic. Prey availability was estimated through standardized invertebrate sampling. The diet of the two warblers was significantly different and included arthropods belonging to the orders Araneida, Coleoptera, Hymenoptera, Hemiptera, Diptera, Mantodea and Orthoptera. The most frequently found prey were Araneida and Coleoptera in the diet of Savi's Warblers, and Hymenoptera and Coleoptera in the diet of Great Reed Warblers. Both species positively selected Araneida and Coleoptera and avoided Diptera, while for other arthropod taxa prey selection differed between the two warbler species.

Key words: apomorphine, bird diet, insectivorous passerines, prey selection

${ }^{1}$ Instituto Cavanilles de Biodiversidad y Biología Evolutiva, Universidad de Valencia, Valencia, Spain; ${ }^{2} \mathrm{IGIC}$, Universitat Politècnica de Valencia, Gandía, Spain;

*corresponding author (sferreirocarballal@gmail.com)
\end{abstract}

The Great Reed Warbler Acrocephalus arundinaceus and the Savi's Warbler Locustella luscinioides are both insectivorous songbirds which typically breed in reedbeds (Kennerley \& Pearson 2010). Both species are distributed across a wide range, including Europe, West and Central Asia and NW Africa, and both winter in subSaharan Africa (Kennerley \& Pearson 2010). The breeding ecology of these species has been the focus of several studies and some of these have described their diet during the breeding season, which included insects, spiders, small molluscs and, in the case of the Great Reed Warbler, also small vertebrates (Mildenberger 1958, Cardenas et al. 1983, Pikulski 1986, Dyrcz \& Flinks 2000, Dyrcz 2016, Pearson 2016). However, diet studies concerning Mediterranean populations are scarce (Cardenas et al. 1983), and information about prey selection is still poor and available only for the Great Reed Warbler (Dyrcz \& Flinks 2000).

In this study, our aims were to describe the diet composition and the prey selection of the Great Reed Warbler and the Savi's Warbler at a sympatric breeding site in Spain, and to assess the occurrence of dietary differences between them.

\section{Methods}

COLLECTION OF FIELD DATA

Fieldwork was conducted during the breeding season of 2012 (10-30 April, 31 May-8 June and 2-5 July) and 2015 (June) in the Marjal de Pego-Oliva $\left(38^{\circ} 52^{\prime} \mathrm{N}\right.$, $0^{\circ} 04^{\prime} \mathrm{W}$ ) in Spain. This coastal marshland (1250 ha) includes large areas of reedbeds (dominated by Phragmites australis and Thypha angustifolia), rice fields, and 

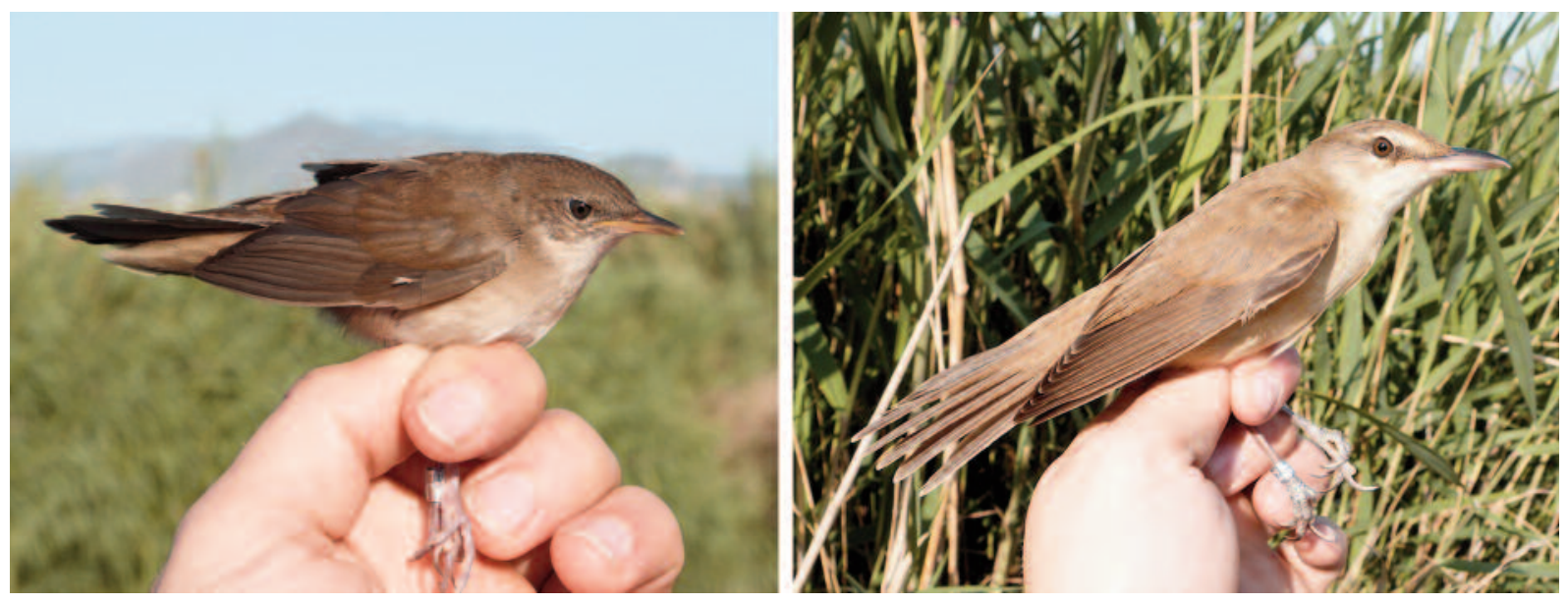

A Savi's Warbler Locustella luscinioides (left) and a Great Reed Warbler Acrocephalus arundinaceus (right), captured in the study area at Marjal de Pego-Oliva (Valencia-Alicante), Spain (photo Carlos Mompó, 25 June 2015).

open water (Urios et al. 1993). To obtain food samples, we used apomorphine as an emetic (i.e. a substance which induces regurgitation), since its effectiveness on our study species has been tested in a previous study (Ceresa et al. 2014) and several researchers demonstrated its safety for birds (e.g. Díaz 1989, Poulin et al. 2002, Ceresa et al. 2014). Birds were captured using mist nets (16-mm mesh) during sampling sessions of four hours, always starting $30 \mathrm{~min}$ before dawn. Following Ceresa et al. (2014), captured birds were ringed, then two drops of a fresh saturated solution of apomorphine (0.04 $\mathrm{g}$ of hydrochloride hemihydrate per $\mathrm{ml}$ of water) were placed on each eye with a $1-\mathrm{ml}$ pipette; birds were then held until the liquid was totally absorbed (c. 5 min). After that, birds were placed in a small, dark box lined with absorbent paper for $20 \mathrm{~min}$ to collect the regurgitated food, and we then released them. No individual bird was resampled.

We obtained information about prey availability by standardized invertebrate sampling, carried out in the reedbed through sweep-netting along one transect (c. $125 \mathrm{~m}$ long) located in the same area where birds were captured. Sampling took place four hours after dawn and consisted of hitting vegetation (mainly P. australis and T. angustifolia) with the net ring from the bottom upwards, 125 times and alternatively on both sides of the trail (Poulin et al. 2002). This method allows for sampling a large variety of invertebrate taxa from the reedbed vegetation which is the main foraging substrate of our study species (Poulin \& Lefebvre 1997, Poulin et al. 2002).

\section{PREY DETERMINATION}

The samples of regurgitated food were examined using

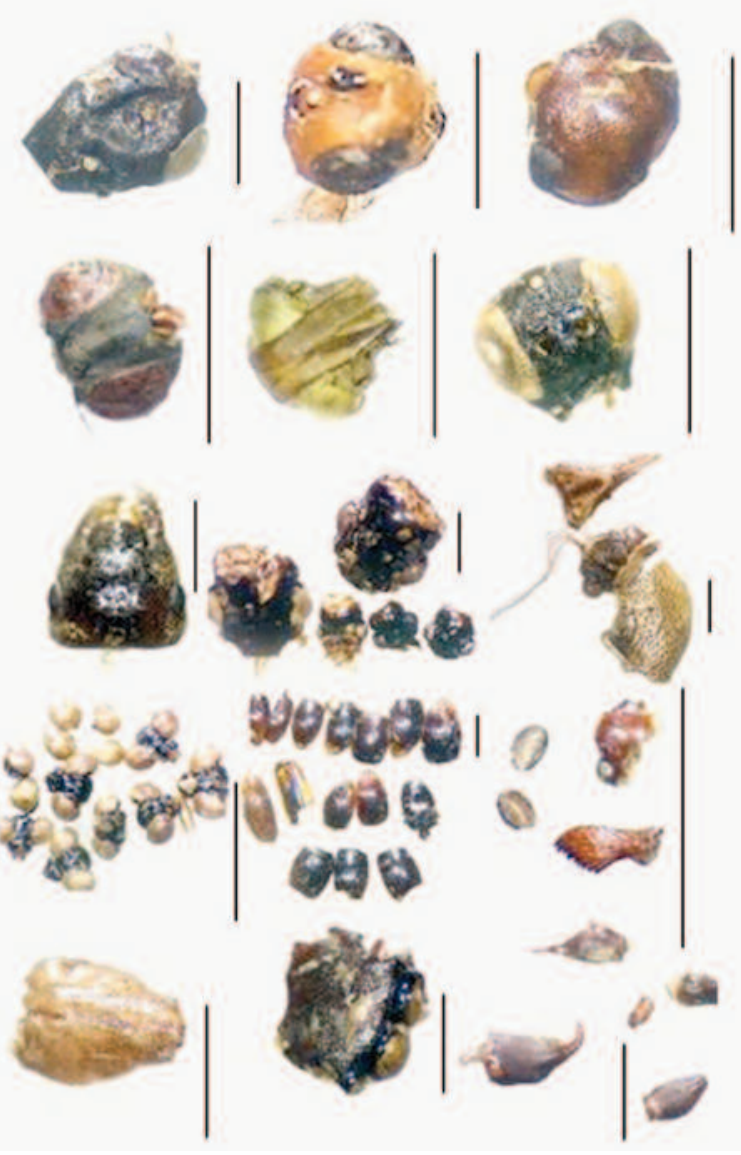

Diet samples collected from regurgitated food. From left to right: row 1: heads of Hymenoptera (2x), and of Hemiptera; 2: heads of Diptera, Mantodea, Diptera; 3: heads of Hymenoptera, Coleoptera, pieces of Hemiptera; 4: heads of Mantodea, elytra of Coleoptera, mouth pieces of Hymenoptera and head of Hemiptera; 5: different pieces of Araneida. Lines depict $1 \mathrm{~mm}$. 
a binocular magnifying glass. Prey was determined to the level of order using a reference collection created with invertebrates sampled in the study area (see Ceresa et al. 2016). For each sample, the minimum number of individuals of each prey type was calculated by counting body parts (Carlisle \& Holberton 2006, Orłowski \& Karg 2013).

\section{STATISTICAL ANALYSIS}

Ivlev's Electivity Index (Ivlev 1961) was used to calculate food preference. In the Ivlev's Electivity Index, values near to -1 express those groups scarcely preyed upon compared to their availability in the environment, while values close to 1 indicate that the proportion of a prey group is larger in the diet than in the environment. Values near zero indicate similar proportions of a prey type in the diet and in the environment. A multivariate analysis of variance (MANOVA) was used to compare the diet composition of the two species, using SPSS v. 19 (Nourisis 2010).

\section{Results}

We obtained 26 food samples from Savi's Warblers (2012: $n=8,2015: n=18$ ) and 14 from Great Reed Warblers (2012: $n=9,2015: n=5)$. From the total of 40 regurgitated samples we obtained 217 recognizable food items, which were identified by physical characteristics, such as wings, elytra, legs, heads, eyes, antennae, mouthparts, and exoskeleton fragments. The mean number of prey items per sample was $4.38 \pm 1.39$ (SE) for Savi's Warbler and $7.36 \pm 2.41$ for Great Reed Warbler.

\section{DIET COMPOSITION}

In the diet of both species we found six orders of hexapods: Hemiptera, Hymenoptera, Diptera, Coleoptera, Orthoptera and Mantodea, as well as a non-insect order, Araneida (Table1). The diets of the two species were significantly different $\left(F_{5,32}=3.11, P=0.021\right)$. Great Reed Warblers appeared to consume more Hymenoptera and Coleoptera than Savi's Warblers, whereas Savi's Warblers consumed more Araneida. Mantodea were found in the diet of Savi's Warblers but not in the diet of Great Reed Warblers (Table1).

\section{PREY SELECTION}

Among the invertebrates collected in the environment, we found a clear dominance of the order Diptera. A variety of other taxa (Thysanoptera, Parasitiformes, Psocoptera, Neuroptera, Odonata, Lepidoptera, Glomerida and Collembola) were found in the environment but not in the diets of the two warblers. According to Ivlev's Electivity Index, both species clearly preferred Araneida and Coleoptera; whereas Diptera were captured in low proportions in comparison to their abundance. Great Reed Warblers also showed a clear preference for Hymenoptera (Figure 1).

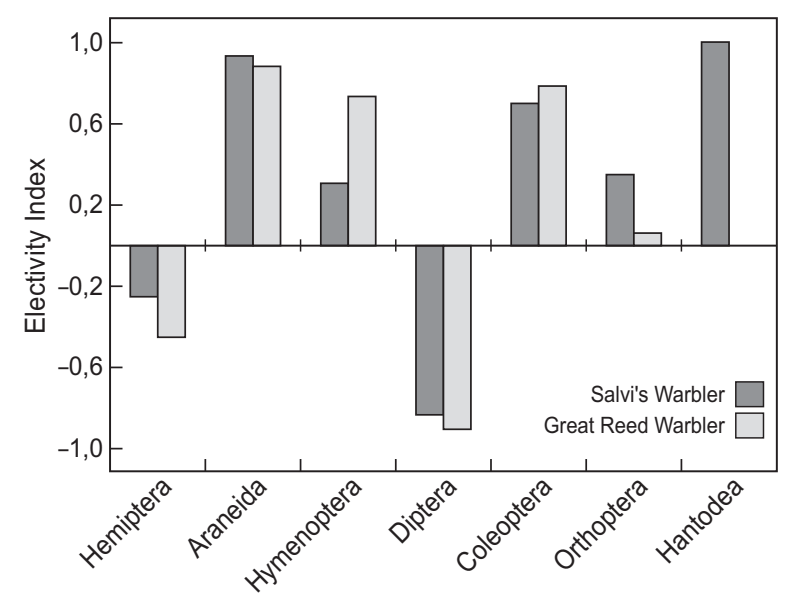

Figure 1. Prey selection of Savi's Warbler and Great Reed Warbler according to the Ivlev's Electivity Index.

Table 1. Number of individuals and relative frequencies of the prey types in food samples of Savi's Warbler $(n=26)$ and Great Reed Warbler $(n=14)$, collected during the breeding season of years 2012 and 2015.

\begin{tabular}{lcccc}
\hline \multirow{2}{*}{ Order } & \multicolumn{2}{c}{ Savi's Warbler } & \multicolumn{2}{c}{ Great Reed Warbler } \\
\cline { 2 - 4 } & $n$ individuals & proportion & $n$ individuals & proportion \\
\hline Hemiptera & 19 & 0.17 & 11 & 0.11 \\
Araneida & 43 & 0.38 & 21 & 0.20 \\
Hymenoptera & 13 & 0.11 & 41 & 0.40 \\
Diptera & 6 & 0.05 & 3 & 0.03 \\
Coleoptera & 20 & 0.18 & 1 & 0.25 \\
Orthoptera & 2 & 0.02 & 0 & 0.01 \\
Mantodea & 11 & 0.10 & 103 & 0.00 \\
Total & 114 & 1.00 & & 1.00 \\
\hline
\end{tabular}




\section{Discussion}

\section{DIET COMPARISON BETWEEN SPECIES}

Our results indicate a significant difference in the use of food resources between our study species, and especially in their exploitation of Hymenoptera. In situations of low food availability, the observed differences may reduce interspecific competitive interactions over food. However, although such differences may reflect true diet differentiation, they may also be an effect of limited sample size. In addition, we possibly would have obtained somewhat different results if prey had been identified to a lower taxonomic level, such as to the level of individual families.

\section{PREY SELECTION}

Based on diet composition and prey availability, we found evidence for prey selection in both warblers (Figure 1). Concerning the Great Reed Warbler, its preference for Araneida and Coleoptera and the underexploitation of Diptera is consistent with the study by Dyrcz \& Flinks (2000) in Poland, although they did not observe the preference for Hymenoptera. In our study, Great Reed Warblers did not capture a prey range as broad as that cited in the literature, where the orders Lepidoptera, Trichoptera, Odonata and Neuroptera were also found in the diet (Cardenas et al. 1983, Dyrcz \& Flinks 2000). However, these studies were based on a larger number of food samples and these taxa did not represent an important part of the diet. Thus, considering that we found these groups in the environment, the reason for their absence in the diet at our study site could be their only occasional consumption and the relatively small number of food samples that we analysed. Possibly for the same reasons, the diet of Savi's Warblers was also missing some invertebrate taxa which occurred in the environment and are reported as prey species in the literature (Lepidoptera, Odonata and small molluscs; Dyrcz 2016). As far as we know, Mantodea have never been found before in the diet of Savi's Warblers. The scarce occurrence of Diptera in the diet of this species contrasts with previous studies done in Central Europe (Mildenberger 1958, Pikulski 1986).

\section{CONCLUSIONS}

We conclude that (1) the diets of Savi's Warblers and Great Reed Warblers at a marshland in eastern Spain consisted of arthropods belonging to the orders Araneida, Hymenoptera, Hemiptera, Coleoptera, Diptera, Orthoptera and, only in Savi's Warbler, Mantodea, that (2) the most frequently occurring prey were Araneida and Coleoptera in the diet of Savi's Warblers, and Hymenoptera and Coleoptera in the diet of Great
Reed Warblers; while Mantodea and Orthoptera were the least consumed prey, that (3) the diet composition of the two warblers differed significantly, and that both warbler species preferred Araneida and Coleoptera, whereas Diptera were captured in lower proportions than appeared in the environment. Selection of other prey taxa was partly different between the two species.

We are grateful to G. Assandri, D. Beneyto, M. Delandés, P. Lucio, M. Marín, C. Mompó, M. Morganti, R. Oliver, R. Piculo, E. Pons, R. Sánchez-Serrano and D. Vidal for their help with the fieldwork, and to S. Añó, N. Ibañez and J. Villarroya for their help in counting and classifying invertebrates. We would like to thank the authorities of the Marjal de Pego-Oliva Natural Park and the Servei de Conservació de la Biodiversitat de la Generalitat Valenciana for providing the facilities to work in protected areas, and for providing the relevant permits. The present work has been partly financed by Projects CGL200502041 and CGL2010-21933/CO2-02 of the Spanish Ministry of Science and Innovation. FC was supported by an Atraent talent grant from the University of Valencia. Juan A. Amat and two anonymous reviewers contributed to improve an earlier version of the manuscript.

\section{References}

Cardenas A.M., Torres J.A. \& Bach C. 1983. Estudio comparado del régimen alimentario de Acrocephalus arundinaceus y $A$. scirpaceus en la laguna de Zoñar. Ardeola 30: 33-34.

Carlisle J.D. \& Holberton R.L. 2006. Relative efficiency of fecal versus regurgitated samples for assessing diet and the deleterious effects of a tartar on migratory birds. J. Field Ornithol. 77: 126-135.

Ceresa F., Belda E.J., Gómez J., Miñana I.J., Soler L., Villarroya J. \& Monrós, J.S. 2016. Differences in time and space use between two sympatric Acrocephalus warblers with similar diets. Bird Study 63: 172-180.

Ceresa F., Belda E.J. \& Monrós J.S. 2014. Apomorphine as an emetic for insectivorous songbirds: effectiveness and postrelease effects on survival and mass change. J. Field Ornithol. 85:213-220.

Díaz M. 1989. Eficacia de un emético (apomorfina) para el estudio de las dietas de paseriformes granívoros. Ardeola 36: 185-191.

Dyrcz A. 2016. Great Reed-warbler (Acrocephalus arundinaceus). In: del Hoyo J., Elliott A., Sargatal J., Christie D.A. \& de Juana, E. (eds) Handbook of the Birds of the World Alive. Lynx Edicions, Barcelona. (accessed 23 September 2016)

Dyrcz A. \& Flinks H. 2000. Potential food resources and nestling food in the Great Reed Warbler (Acrocephalus arundinaceus arundinaceus) and Eastern Great Reed Warbler (Acrocephalus arundinaceus orientalis). J. Ornithol 141: 351-360.

Ivlev V.S. 1961. Experimental ecology of the feeding of fishes. Yale University Press. Connecticut.

Kennerley P. \& Pearson D. 2010. Reed and bush warblers. Christopher Helm Publishers Ltd.

Mildenberger H. 1958. Zur Ökologie und Brutbiologie des Rohrschwirls (Locustella luscinioides). J. Ornithol. 99: 92-99. 
Nourisis M.J. 2010. 2010 IBM SPSS statistics 19 guide to data analysis. Pearson, Minneapolis, MN.

Orłowski G. \& Karg J. 2013. Diet breadth and overlap in three sympatric aerial insectivorous birds at the same location. Bird Study 60: 475-483.

Pearson D. 2016. Savi's Warbler (Locustella luscinioides). In: del Hoyo J., Elliott A., Sargatal J., Christie D.A. \& de Juana E. (eds) Handbook of the Birds of the World Alive. Lynx Edicions, Barcelona. (accessed 23 September 2016)

Pikulski A. 1986. Breeding biology and ecology of Savi's warbler (Locustella luscinioides) at Milicz fish-ponds. PtakiSlaska 4: 2-39.

Poulin B. \& Lefebvre G. 1997. Estimation of arthropods available to birds: effect of trapping technique, prey distribution, and bird diet. J. Field Ornithol. 68: 426-442.

Poulin B., Lefebvre G. \& Mauchamp A. 2002. Habitat requirements of passerines and reedbed management in southern France. Biol. Conserv. 107: 315-325.

Urios V., Donat P. \& Viñals M.J. 1993. La marjal de Pego-Oliva. Instituto de Estudios Comarcales de la Marina Alta.

\section{Samenvatting}

In dit onderzoek hebben wij het voedsel van de Snor Locustella luscinioides en de Grote Karekiet Acrocephalus arundinaceus in een broedgebied in Spanje, de Marjal de Pego-Oliva (ValenciaAlicante) geanalyseerd. Van beide soorten is de dieetsamenstelling onderzocht en is er gekeken of de twee soorten een voorkeur voor bepaalde prooisoorten hadden. Het voedsel van de jongen werd verkregen door de ouders die voedsel aanbrachten te vangen en te laten braken met behulp van een braakmiddel (apomorfine), een onderzoekmethode waarvan bekend is dat de vogels er geen nadelige gevolgen van ondervinden. De voedselbeschikbaarheid in het riet werd op een gestandaardiseerde wijze gemeten met een vangnet. Het voedsel van de twee soorten bestond uit spinnen (Araneida), kevers (Coleoptera), vliesvleugeligen (Hymenoptera), halfvleugeligen (Hemiptera), vliegen en muggen (Diptera), bidsprinkhanen (Mantodea) en rechtvleugeligen (Orthoptera). De meest voorkomende prooien in het voedsel van de Snor waren spinnen en kevers, in dat van de Grote Karekiet vliesvleugeligen en kevers. Beide soorten hadden een voorkeur voor spinnen en kevers en een afkeer van vliegen. Voor de andere geleedpotigen verschilde de prooiselectie tussen de twee soorten.

Corresponding editor: Peter Korsten Received 27 October 2016; accepted 15 March 2017 


